\title{
KONSUMSI SUSU FORMULA SEBAGAI FAKTOR RISIKO KEGEMUKAN PADA BALITA DI KOTA SEMARANG
}

\author{
Citra Tristi Utami, Hartanti Sandi Wijayanti*) \\ ${ }^{*}$ Program Studi Ilmu Gizi Fakultas Kedokteran Universitas Diponegoro \\ Jln. Prof. H. Soedarto, SH., Semarang, Telp (024) 8453708, Email : gizifk@undip.ac.id
}

\begin{abstract}
Background: The incidence of overweight have been found at an early age, starting from 0-5 years old. Formula feeding with high energy and protein in early growth could increase the risk of weight gain and overweight in children. The aim of this reasearch was to evaluate the formula milk consumption as risk factor of childhood overweight in Semarang City. Method: This research was a case control study. Subjects were 27 children in case group and 27 children in control group aged 2-5 years old. Overweight was determined by height/weight z-score index. The first time of formula milk consumption and the average quantity of formula milk consumption were collected by questionaire. Energy, carbohydrate, fat, and protein intake were assessed by semi-quantitative food frequency questionaire (SQ-FFQ). The bivariate correlation was analyzed by Chi-square test. The multivariate correlation was analyzed by Multiple Logistic Regression.

Result: The results showed $81.5 \%$ subject in case group was given formula milk under 6 months old, whereas in control group was $48.1 \%$. Subjects in case group who consumed formula milk $>100 \mathrm{~g} / \mathrm{d}$ was $77.8 \%$, whereas in control group was 33.3\%. There were significant difference at first time of formula milk consumption $(p=0.004)$ and average quantity of formula milk $(p=0.001)$ between case and control group. Formula milk consumption $>100 \mathrm{~g} /$ d significantly correlated to childhood overweight after adjusting energy, protein, carbohydrate, and fat intake $(p=0.009)$. Children who consumed formula milk $>100 \mathrm{~g} / \mathrm{d}$ were at increased risk of overweight 7.0-fold than children who consumed formula milk $\leq 100$ g/d.
\end{abstract}

Conclusion: Children who consumed formula milk $>100 \mathrm{~g} / \mathrm{d}$ were at increased risk of overweight 7.0-fold.

Keywords: Overweight, children under five years old, formula milk

\section{ABSTRAK}

Latar belakang: Saat ini kegemukan telah banyak ditemukan pada umur dini, yakni mulai dari umur 0-5 tahun. Pemberian susu formula dengan kandungan energi dan protein yang tinggi pada awal pertumbuhan dapat meningkatkan risiko terjadinya kegemukan pada balita. Penelitian ini bertujuan untuk menganalisis hubungan antara konsumsi susu formula dengan kegemukan pada balita di Kota Semarang.

Metode: Desain penelitian ini adalah kasus-kontrol. Subjek penelitian terdiri dari 27 subjek pada kelompok kasus dan 27 subjek pada kelompok kontrol dengan umur 2-5 tahun. Kriteria kegemukan menggunakan indikator z-score BB/TB. Waktu pertama pemberian susu formula dan berat rata-rata konsumsi susu formula diperoleh melalui kuisioner. Asupan energi, karbohidrat, protein dan lemak dihitung dengan formulir semi quantitative-food frequency questionaire (SQFFQ). Analisis bivariat menggunakan uji Chi-square. Analisis Multivariat menggunakan Regresi Logistik Ganda.

Hasil: Hasil penelitian menunjukkan $85.2 \%$ subjek pada kelompok kasus pertama kali mengonsumsi susu formula sebelum umur 6 bulan, sedangkan pada kelompok kontrol hanya 48.1\%. Pada kelompok kasus, 77.8\% subjek mengonsumsi susu formula $>100$ g/hari dibandingkan dengan kelompok kontrol hanya 33.3\% dari subjek. Terdapat perbedaan pada waktu pertama pemberian susu formula $(p=0.004)$ dan konsumsi susu formula $>100$ g/hari $(p=0.001)$ antara kelompok kasus dan kelompok kontrol. Konsumsi susu formula >100 g/hari berhubungan secara signifikan dengan kegemukan pada balita setelah dikontrol dengan asupan energi, protein, karbohidrat dan lemak $(p=0.009)$. Balita yang mengonsumsi susu formula $>100$ g/hari berisiko 7 kali lipat mengalami kegemukan dibandingkan dengan balita yang mengonsumsi $\leq 100 \mathrm{~g} / \mathrm{hari}$.

Simpulan: Balita yang mengonsumsi berat rata-rata susu formula >100 g/hari berisiko 7.0 kali mengalami kegemukan. Kata kunci: Susu formula, kegemukan, balita

\section{PENDAHULUAN}

Prevalensi obesitas dan gizi lebih di dunia pada anak umur 0-5 tahun pada tahun 1990 mencapai 4.2\% dan mengalami kenaikan menjadi $7.8 \%$ pada tahun 2015, serta diperkirakan mencapai $9.1 \%$ pada tahun 2020. ${ }^{1}$ Berdasarkan data Riset Kesehatan Dasar (Riskesdas) tahun 2013, prevalensi gizi lebih pada umur balita mencapai $11.9 \%$. Sementara itu, diketahui pula bahwa Jawa Tengah merupakan salah satu dari 12 provinsi di Indonesia yang memiliki masalah balita gizi lebih di atas angka nasional yaitu mencapai $12 \% .^{2}$

Faktor yang erat kaitannya dengan kegemukan pada balita adalah faktor asupan makanan. ${ }^{3} \quad$ Kelebihan asupan makanan yang dikonsumsi tanpa disertai penggunaan energi yang 
memadai akan menyebabkan peningkatan penyimpanan energi dalam sel lemak yang berakibat meningkatnya jumlah dan ukuran sel lemak, yang dapat mengakibatkan terjadinya kegemukan pada balita. ${ }^{3}$ Sementara itu, faktor yang erat dengan asupan makanan dan kejadian gizi lebih pada balita adalah pola asuh ibu dalam memberikan makanan pada balita yang kurang tepat. ${ }^{4}$

Ketidaktepatan pola asuh ibu berkaitan dengan asupan makanan balita yang sering ditemui di masyarakat adalah dalam pemberian Air Susu Ibu (ASI) dan susu formula. Seharusnya, seorang bayi umur 0-6 bulan diberikan ASI secara eksklusif, dan kemudian dilanjutkan dengan pemberian ASI dengan didampingi Makanan Pendamping Air Susu Ibu (MPASI) sampai dengan umur 24 bulan. Berdasarkan data Dinas Kesehatan Republik Indonesia (Dinkes RI) tahun 2013, diketahui cakupan pemberian ASI di Indonesia hanya sebesar $54.3 \%$, dan cakupan pemberian makanan prelakteal pada anak umur 0-23 bulan mencapai $44.3 \%$, dengan makanan yang paling banyak diberikan pada bayi adalah susu formula, dengan cakupan sebesar $79.8 \%{ }^{5}$

Penelitian yang dilakukan oleh Gunther di Jerman menunjukkan bahwa balita yang mengalami kegemukan berkaitan dengan konsumsi protein dalam tingkat tinggi yaitu dari susu formula pada umur 12 bulan. ${ }^{11}$ Selain itu, diketahui pula bahwa anak-anak yang mengonsumsi susu formula atau makanan komplementer pada umur dibawah 4 bulan dapat meningkatkan berat badan bayi. ${ }^{6}$ Hal ini menunjukkan bahwa waktu awal konsumsi susu formula dapat berkaitan dengan peningkatan berat badan dan risiko terjadinya kegemukan pada anak. ${ }^{7}$

Pemberian susu formula dengan kandungan energi dan protein yang tinggi pada awal kehidupan dapat meningkatkan risiko terjadinya peningkatan berat badan dan kegemukan pada anak-anak dikarenakan jumlah asupan energi yang melebihi kebutuhan, dan asupan protein yang tinggi dapat meningkatkan pelepasan hormon insulin dan insulin like growth factor-1 (IGF-1) yang mana hormon tersebut dapat meningkatkan aktivitas adipogenik dan mendorong kenaikan berat badan. ${ }^{8,9}$ Menurut penelitian yang dilakukan oleh David Hopkins dkk. pemberian susu formula $\geq 200 \mathrm{~g} /$ hari pada masa bayi berkaitan dengan peningkatan kecepatan dalam pertambahan berat badan dan tinggi badan anak dibandingkan dengan ASI. ${ }^{10}$ Pada penelitian lain yang dilakukan Puji Lestari di Kota Semarang pada bayi usia 0-6 bulan, konsumsi susu formula antara 15$24 \mathrm{x} /$ hari dengan takaran $11,3 \mathrm{~g}$ per 1 sendok susu atau setara dengan 170-270 g/hari dapat menyebabkan kegemukan pada anak. ${ }^{11}$

Berdasarkan uraian diatas, dapat dikembangkan penelitian yang dilakukan untuk mengetahui hubungan konsumsi susu formula sebagai faktor risiko kegemukan pada balita di Kota Semarang.

\section{METODE}

Penelitian ini merupakan penelitian deskriptif analitik dengan ruang lingkup gizi masyarakat dan menggunakan desain penelitian kasus-kontrol. Penelitian ini dilaksanakan di Kelurahan Bangetayu Kulon dan Kelurahan Jangli, Semarang pada bulan September - Oktober 2016. Populasi target dalam peneltian ini adalah balita gemuk dan tidak gemuk umur 2-5 tahun yang terdapat di Kota Semarang, dan populasi terjangkau adalah balita gemuk dan tidak gemuk umur 2-5 tahun yang terdapat di Kecamatan Genuk dan Kecamatan Tembalang, Semarang. Perhitungan sampel menggunakan rumus hipotesis dengan odd ratio diketahui jumlah minimal sampel penelitian adalah 25 orang/kelompok. ${ }^{12}$

Wilayah penelitian ditentukan berdasarkan tingginya angka prevalensi gizi lebih untuk masingmasing kecamatan di Kota Semarang. Kecamatan Genuk merupakan kecamatan dengan prevalensi gemuk tertinggi di Kota Semarang yaitu 29.0\% dengan Kelurahan Bangetayu Kulon sebagai kelurahan dengan prevalensi gemuk tertinggi di Kecamatan Genuk. Setelah melakukan screening di Kelurahan Bangetayu Kulon didapatkan 15 pasang sampel penelitian. Jumlah tersebut belum memenuhi jumlah minimal sampel penelitian, maka wilayah penelitian diperluas ke Kecamatan Tembalang yang juga memiliki prevalensi gemuk tinggi di Kota Semarang dengan Kelurahan Jangli sebagai kelurahan dengan prevalensi gemuk tertinggi. Tidak ada drop out pada sampel penelitian.

Variabel independen terdiri dari waktu pertama pemberian susu formula dan berat rata-rata konsumsi susu formula. Variabel dependen dalam penelitian ini adalah kegemukan pada balita. Variabel yang menjadi perancu adalah asupan energi, asupan karbohidrat, asupan protein dan asupan lemak balita. Waktu pertama pemberian susu formula didefinisikan sebagai umur balita pertama kali mengonsumsi susu formula yang dikategorikan menjadi sebelum dan sesudah 6 bulan. ${ }^{2}$ Berat rata-rata pemberian susu formula didefinisikan sebagai berat rata-rata susu formula yang dikonsumsi balita per hari pada umur 012 bulan yang dikategorikan berdasarkan nilai di atas dan di bawah median konsumsi susu formula dari keseluruhan sampel. Asupan makanan diukur menggunakan formulir Semi Quantitative-Food Frequency Questionnaire (SQ-FFQ) dengan rincian asupan yang dikonsumsi dalam 1 tahun terakhir.

Kriteria inklusi dalam penelitian diantaranya bersedia mengisi informed consent (orangtua/wali bayi), ibu dengan balita umur 2-5 tahun di Kelurahan 
Bangetayu Kulon dan Kelurahan Jangli, balita umur 2-5 tahun dengan nilai Z-skor > $2 \mathrm{SD}$ BB/TB untuk kelompok kasus, balita umur 2-5 tahun dengan nilai Z-skor -2 SD sampai dengan $2 \mathrm{SD} \mathrm{BB} / \mathrm{TB}$ untuk kelompok kontrol. Kriteria eksklusi diantaranya balita pindah tempat tinggal saat penelitian berlangsung, mengundurkan diri sebagai subjek penelitian, meninggal, balita dalam keadaan sakit atau dalam perawatan dokter.

Data awal subjek diperoleh dari masingmasing Posyandu di setiap kelurahan. Subjek berjumlah 27 anak untuk masing-masing kelompok. Responden penelitian adalah ibu balita. Pemilihan kelompok kontrol dilakukan dengan matching by design untuk kelompok jenis kelamin.

Data primer dalam penelitian ini diantaranya data identitas subjek diperoleh dari hasil wawancara langsung dengan ibu subjek menggunakan kuisioner penelitian, meliputi nama, jenis kelamin, alamat, tanggal lahir, berat badan, panjang badan, waktu pertama konsumsi susu formula, berat konsumsi susu formula, riwayat pemberian ASI, pekerjaan orangtua, pendidikan orangtua, riwayat konsumsi makan anak dengan menggunakan formulir SQ-FFQ, riwayat kesehatan anak, dan riwayat pemberian MP-ASI. Data sekunder dalam penelitian adalah data dari Dinkes Kota Semarang dan Posyandu. Instrumen penelitian yang digunakan diantaranya kuisioner penelitian, formulir SQ-FFQ, timbangan berat badan digital dengan ketelitian $0,1 \mathrm{~kg}$, microtoise dengan ketelitian 0,1 cm, aplikasi WHO antro 2005 untuk menghitung hasil nilai $z$-score anak.

Analisis univariat dilakukan untuk menyajikan data secara deskriptif dengan menggunakan tabel distribusi. Deskripsi data numerik disajikan dalam bentuk rerata, simpangan baku, nilai median, nilai minimum dan maksimum. Data kategorik dalam bentuk proporsi atau persentase. Analisis bivariat dilakukan untuk mengetahui hubungan variabel dependen dan independen dalam bentuk tabulasi silang (cross-tab) menggunakan uji chi-square. Analisis multivariat menggunakan uji regresi logistik ganda.

\section{HASIL PENELITIAN}

Jumlah subjek dalam penelitian ini adalah 54 orang balita yang terdiri dari 27 orang balita dalam kategori gemuk (kelompok kasus) dan 27 orang balita dalam kategori normal (kelompok kontrol). Secara statistik, tidak terdapat perbedaan karakteristik antara subjek pada kelompok kasus dan kelompok kontrol, antara lain pada variabel jenis kelamin, pendapatan orangtua, pendidikan ayah, pendidikan ibu dan status bekerja ibu (tabel 1). Apabila ditinjau dari segi antropometri, tidak terdapat perbedaan pada tinggi badan antara kelompok kasus dan kelompok kontrol, tetapi terdapat perbedaan yang signifikan pada berat badan ( $\mathrm{p}<0.001)$ dan indeks $z$-score BB/TB anak ( $p$ $<0.001)$ (tabel 2).

Tabel 1 . Karakteristik dasar subjek penelitian

\begin{tabular}{|c|c|c|c|}
\hline Karakteristik & Kasus $(n=27)$ & Kontrol $(n=27)$ & $\mathbf{p}$ \\
\hline \multicolumn{4}{|l|}{ Jenis kelamin anak } \\
\hline laki-laki & $14(51.85 \%)$ & $14(51.85 \%)$ & \multirow[t]{2}{*}{$1.000^{\mathrm{a}}$} \\
\hline perempuan & $13(48.14 \%)$ & $13(48.14 \%)$ & \\
\hline \multicolumn{4}{|l|}{ Pendapatan Orangtua } \\
\hline Di bawah UMR & & & \multirow{3}{*}{$0.772^{\mathrm{a}}$} \\
\hline ( < Rp. 1.900.000/bulan) & $4(14.82 \%)$ & $6(22.21 \%)$ & \\
\hline UMR ( $\geq$ Rp. 1.900.000/bulan) & $23(85.18 \%)$ & $21(77.79 \%)$ & \\
\hline \multicolumn{4}{|l|}{ Pendidikan Ayah } \\
\hline dasar (SD dan SMP) & $11(40.74 \%)$ & $12(44.83 \%)$ & \multirow[t]{3}{*}{$1.000^{\circ}$} \\
\hline menengah (SMA) & $13(48.14 \%)$ & $11(41.36 \%)$ & \\
\hline tinggi (D1/D2/D3/S1/S2/S3) & $3(11.11 \%)$ & $4(14.81 \%)$ & \\
\hline \multicolumn{4}{|l|}{ Pendidikan Ibu } \\
\hline dasar (SD dan SMP) & $12(44.44 \%)$ & $12(44.44 \%)$ & \multirow[t]{3}{*}{$1.000^{\mathrm{a}}$} \\
\hline menengah (SMA) & $11(40.74 \%)$ & $13(48.14 \%)$ & \\
\hline tinggi (D1/D2/D3/S1/S2/S3) & $4(14.81 \%)$ & $2(7.40 \%)$ & \\
\hline \multicolumn{4}{|l|}{ Status Bekerja Ibu } \\
\hline Bekerja & $13(48.14 \%)$ & $11(41.37 \%)$ & \multirow[t]{2}{*}{$0.413^{\mathrm{a}}$} \\
\hline Tidak Bekerja & $14(51.85 \%)$ & $16(58.62 \%)$ & \\
\hline
\end{tabular}

${ }^{a}$ dianalisis menggunakan uji chi-square

Waktu pertama pemberian MP-ASI tidak berbeda antara kelompok kasus dan kelompok kontrol (Tabel 2). Ditinjau dari asupan zat gizi kedua kelompok, terdapat perbedaan yang signifikan pada asupan energi $(\mathrm{p}<0.001)$, karbohidrat $(\mathrm{p}=0.004)$ dan lemak $(p=0.006)$ anak per hari, tetapi tidak terdapat perbedaan pada asupan protein (tabel 3 ). 
Tabel 2. Karakteristik usia, status gizi dan waktu pertama pemberian MP-ASI subjek penelitian

\begin{tabular}{|c|c|c|c|c|c|}
\hline & \multicolumn{2}{|r|}{ Kasus } & \multicolumn{2}{|r|}{ Kontrol } & \multirow{2}{*}{$\mathbf{p}$} \\
\hline & Mean \pm SD & Median (min,max) & Mean \pm SD & Median (min,max) & \\
\hline $\begin{array}{l}\text { Umur } \\
\text { (tahun) }\end{array}$ & $3.67 \pm 0.81$ & $3.86(1.98,4.87)$ & $3.62 \pm 0.77$ & $3.79(2.35,4.98)$ & $0.819^{\mathrm{a}}$ \\
\hline BB (kg) & $20.2 \pm 4.2$ & $20.0(13.2,28.4)$ & $14.2 \pm 2.4$ & $14.1(10.3,20.0)$ & $0.000^{\mathrm{a}}$ \\
\hline $\mathrm{TB}(\mathrm{cm})$ & $97.9 \pm 8.7$ & $99.5(81.5,111.6)$ & $95.0 \pm 6.7$ & $96.2(82.7,110.1)$ & $0.173^{\mathrm{a}}$ \\
\hline Z-score & & & & & \\
\hline $\begin{array}{l}\text { BB/TB (SD) } \\
\text { Waktu MP- }\end{array}$ & $3.37 \pm 1.01$ & $3.19(2.07,5.81)$ & $0.05 \pm 1.08$ & $-0.15(-1.58,2.00)$ & $0.000^{\mathrm{b}}$ \\
\hline ASI & $4.85 \pm 2.49$ & $6.00(0.00,12.00)$ & $4.96 \pm 1.67$ & $6.00(1.00,7.00)$ & $0.730^{\mathrm{b}}$ \\
\hline
\end{tabular}

Tabel 3. Riwayat asupan makanan subjek penelitian

\begin{tabular}{|c|c|c|c|}
\hline Karakteristik & Kasus $(n=27)$ & Kontrol $(n=27)$ & $\mathbf{p}$ \\
\hline \multicolumn{4}{|l|}{ Asupan energi } \\
\hline Cukup & $5(18.5 \%)$ & $19(70.4 \%)$ & $<0.001^{\mathrm{a}}$ \\
\hline Lebih & $22(81.5 \%)$ & $8(29.6 \%)$ & \\
\hline \multicolumn{4}{|c|}{ Asupan karbohidrat } \\
\hline Cukup & $13(48.1 \%)$ & $23(85.2 \%)$ & $0.004^{\mathrm{a}}$ \\
\hline Lebih & $14(51.9 \%)$ & $4(14.8 \%)$ & \\
\hline \multicolumn{4}{|l|}{ Asupan protein } \\
\hline Cukup & $14(51.9 \%)$ & $8(29.6 \%)$ & $0.097^{\mathrm{a}}$ \\
\hline Lebih & $13(48.1 \%)$ & $19(70.4 \%)$ & \\
\hline \multicolumn{4}{|l|}{ Asupan lemak } \\
\hline Cukup & $8(29.6 \%)$ & $18(66.7 \%)$ & $0.006^{\mathrm{a}}$ \\
\hline Lebih & $19(70.4 \%)$ & $9(33.3 \%)$ & \\
\hline
\end{tabular}

${ }^{a}$ dianalisis menggunakan uji chi-square

Waktu pertama pemberian susu formula kelompok kontrol. Berat rata-rata konsumsi susu berbeda antara kelompok kasus dan kelompok formula pada kelompok kasus adalah 159.41 g/hari. kontrol. Waktu pertama pemberian susu formula pada Hasil ini lebih tinggi dua kali lipat dibandingkan pada kelompok kasus lebih awal dibandingkan pada kelompok kontrol yaitu $67.05 \mathrm{~g} / \mathrm{hari}$ (tabel 4).

Tabel 4. Karakteristik konsumsi susu formula subjek penelitian

\begin{tabular}{lcccc}
\hline \multicolumn{1}{c}{ Karakteristik } & \multicolumn{2}{c}{ Kasus } & Kontrol \\
\cline { 2 - 5 } & Mean \pm SD & Median (min, max) & Mean \pm SD & Median (min, max) \\
\hline $\begin{array}{l}\text { Waktu pertama } \\
\text { pemberian susu } \\
\text { (bulan) }\end{array}$ & $3.0 \pm 3.2$ & $2.0(0.0,24.0)$ & $10.9 \pm 12.2$ & $6.0(0.0,36.0)$ \\
$\begin{array}{l}\text { Rata-rata } \\
\text { konsumsi susu } \\
\text { formula (g/hari) }\end{array}$ & $159.4 \pm 92.9$ & $153.0(0.0,378.0)$ & $69.1 \pm 100.0$ & $0.0(0.0,295.0)$ \\
\hline
\end{tabular}

Tabel 5 menunjukkan bahwa terdapat perbedaan yang signifikan antara waktu pertama pemberian susu formula $(\mathrm{p}=0.004)$ dan berat ratarata konsumsi susu formula $(\mathrm{p}=0.001)$ pada kedua kelompok subjek penelitian. Waktu pertama pemberian susu formula sebelum umur 6 bulan memiliki risiko 6.19 kali untuk mengalami kegemukan dan berat rata-rata konsumsi susu formula $>100 \mathrm{~g} /$ hari memiliki risiko 7.0 kali untuk mengalami kegemukan.

Tabel 5. Tabel silang konsumsi susu formula subjek penelitian

\begin{tabular}{|c|c|c|c|c|c|}
\hline \multicolumn{2}{|c|}{ Karakteristik } & Kasus n (\%) & Kontrol n (\%) & $\mathbf{p}$ & OR $(95 \%$ CI $)$ \\
\hline $\begin{array}{l}\text { Waktu } \\
\text { formula }\end{array}$ & pemberian & & & & \\
\hline
\end{tabular}




\begin{tabular}{lllll}
\hline $\begin{array}{l}\text { Sebelum umur 6 bulan } \\
\begin{array}{l}\text { Sesudah umur 6 bulan } \\
\text { Berat rata-rata konsumsi susu } \\
\text { formula }\end{array}\end{array}$ & $23(85.2 \%)$ & $13(48.1 \%)$ & 0.004 & $6.19(1.68-22.78)$ \\
$\quad>100 \mathrm{~g} / \mathrm{hari}$ & & & & \\
$\quad \leq 100 \mathrm{~g} / \mathrm{hari}$ & $21(57.9 \%)$ & & & \\
\hline
\end{tabular}

Analisis multivariat digunakan untuk melihat apakah masih ada efek variabel independen terhadap variabel dependen setelah dikontrol dengan variabel perancu. Secara statistik, terdapat dua variabel yang berpengaruh signifikan terhadap kegemukan balita yaitu berat rata-rata susu formula $>100 \mathrm{~g} / \mathrm{hari}$ dan asupan energi. Namun, waktu pertama pemberian susu formula tidak berpengaruh secara signifikan terhadap kegemukan balita setelah dikontrol dengan asupan energi, karbohidrat, lemak dan protein.

Tabel 6. Hasil Analisis Multivariat Regresi Logistik Ganda

\begin{tabular}{lrrr}
\hline \multicolumn{1}{c}{ Variabel } & koefisien & p & \multicolumn{1}{c}{ OR (95\% CI } \\
\hline Asupan energi & 2.59 & 0.001 & $13.3(2.79-63.10)$ \\
Berat rata-rata susu formula $>100 \mathrm{~g} /$ hari & 1.95 & 0.009 & $7.0(1.69-30.27)$ \\
Asupan protein & -1.53 & 0.057 & $0.2(0.04-1.05)$ \\
Konstanta & -1.63 & 0.038 & 0.2 \\
\hline
\end{tabular}

\section{PEMBAHASAN}

Waktu pertama pemberian susu formula berbeda antara kelompok kasus dan kelompok kontrol $(p=0.004)$. Namun, pada kelompok kontrol juga terdapat subjek yang mengonsumsi susu formula sebelum usia 6 bulan yaitu dimulai pada usia 0 bulan. Alasan pemilihan susu formula dibandingkan ASI dapat disebabkan beberapa faktor. Penelitian yang dilakukan oleh Zhang dkk. di China menemukan bahwa sebagian besar alasan ibu memberi susu formula karena merasa suplai ASI tidak cukup bagi anak. ${ }^{13}$ Alasan lainnya adalah karena ibu harus kembali bekerja, pengaruh nenek dan teman dari ibu yang juga memberi susu formula pada anak, pengaruh media persepsi ibu tentang pertumbuhan dan pentingnya susu formula, pengetahuan ibu tentang manfaat ASI kurang, dan persepsi ibu bahwa susu formula memiliki zat gizi yang lebh lengkap karena adanya fortifikasi zat gizi seperti vitamin D dan DHA. ${ }^{13,14,15}$

Balita yang mengonsumsi susu formula sebelum umur 6 bulan berisiko 6.19 kali lebih besar untuk mengalami kegemukan. Hal ini dapat dikarenakan pemberian susu formula yang mempunyai kandungan protein tinggi pada awal kehidupan dapat memodulasi konsentrasi hormon Insulin-like Growth Factor-1 (IGF-1). Hormon IGF1 mengatur pertumbuhan serta mengatur perkembangan jaringan adiposa melalui jalur endokrin. Asupan protein yang tinggi seperti branched-chain amino acids (BCAA) atau asam amino rantai terikat meningkatkan sekresi insulin dan IGF-1 yang berdampak pada peningkatan diferensiasi preadiposit dan penambahan jumlah adiposit dalam tubuh anak. ${ }^{16}$
Waktu pertama konsumsi susu formula pada usia dini dan dampaknya pada kegemukan berkaitan dengan hasil dari beberapa penelitian. Penelitian yang dilakukan oleh Baker pada tahun 2004 bahwa anakanak yang mengonsumsi susu formula pada umur dibawah 4 bulan mempunyai risiko untuk mengalami pertambahan berat badan melebihi normal. ${ }^{7}$ Pada penelitian lain yang dilakukan oleh Debra di Amerika Serikat menunjukkan bahwa anak-anak yang mengalami kegemukan pada umur 4 tahun berkaitan dengan konsumsi susu formula sebelum 2 bulan. ${ }^{17}$ Penelitian yang dilakukan oleh Martina Weber dkk pada balita menunjukkan bahwa balita yang diberikan susu formula pada saat bayi mengalami risiko kegemukan 2.43 kali lebih besar pada umur 5 tahun dibandingkan dengan balita yang tidak diberi susu formula tinggi protein. ${ }^{18}$

Berat rata-rata susu formula yang dikonsumsi berbeda antara kelompok kasus dan kelompok kontrol $(\mathrm{p}=0.001)$. Balita yang mengonsumsi ratarata susu formula $>100 \mathrm{~g} /$ hari berisiko 7.0 kali lebih besar untuk mengalami kegemukan. Hasil penelitian menunjukkan bahwa konsumsi susu formula pada kelompok kasus lebih besar daripada kelompok kontrol. Hasil penelitian ini sejalan dengan penelitian yang dilakukan oleh David Hopkins dkk yaitu pemberian susu formula $\geq 200 \mathrm{~g} / \mathrm{hari}$ pada masa bayi berkaitan dengan peningkatan kecepatan dalam pertambahan berat badan dan tinggi badan anak dibandingkan dengan anak yang hanya diberikan ASI. ${ }^{10}$ Penelitian lain yang dilakukan oleh Puji lestari di Kecamatan Semarang timur diketahui berat ratarata konsumsi susu formula 170-260 g/hari dapat menyebabkan kegemukan pada balita. ${ }^{11}$ Sebuah penelitian dengan desain case control oleh Aspri dkk 
diketahui bahwa anak yang mengkonsumsi susu formula mempunyai risiko mengalami kegemukan 6.2 kali lebih tinggi dibandingkan dengan yang tidak mengkonsumsi susu formula. ${ }^{19}$

Kandungan zat gizi dalam susu formula seharusnya mempunyai jumlah yang ekuivalen dengan ASI. Namun, susu formula yang umumnya dipasarkan mempunyai kandungan energi yang lebih tinggi daripada ASI. Kandungan energi dalam $100 \mathrm{ml}$ susu formula mencapai $77,6 \mathrm{kkal} / 100 \mathrm{ml}$, lebih tinggi jika dibandingkan ASI yang hanya 63,9 kkal/100 ml. Jika konsumsi secara berlebihan terjadi terus menerus akan menyebabkan asupan energi yang jauh lebih besar daripada kebutuhan dan menyebabkan percepatan pertumbuhan anak. $^{20}$ Balita yang mempunyai riwayat asupan energi melebihi kebutuhan mempunyai risiko lebih besar untuk mengalami kegemukan melalui penumpukan jaringan adiposa. ${ }^{21}$ Selain itu, asupan karbohidrat, protein dan lemak apabila dikonsumsi melebihi kebutuhan dapat menyebabkan kegemukan pada balita. ${ }^{22-25}$

Analisis multivariat menunjukkan bahwa konsumsi susu formula dengan berat rata-rata $>100 \mathrm{~g} / \mathrm{hari}$ dan asupan energi masih berpengaruh secara signifikan terhadap kegemukan balita. Hal ini menunjukkan bahwa selain dipengaruhi asupan energi saat ini, kegemukan balita juga dipengaruhi oleh asupan susu formula saat bayi. Akan tetapi, pengaruh waktu pertama pemberian susu formula tidak lagi signifikan terhadap kegemukan balita.

Ada beberapa mekanisme yang mungkin dapat terjadi akibat pemberian susu formula dalam jumlah besar saat bayi terhadap kegemukan pada balita. Pertama, konsumsi susu formula dalam jumlah besar dapat berdampak pada pertambahan berat badan anak hingga usia 2 tahun, tetapi pertambahan tersebut tidak konsisten pada usia setelahnya. ${ }^{16}$ Akan tetapi, berdasarkan penelitian yang dilakukan oleh Gunther di Jerman menunjukkan bahwa anak yang mengonsumsi susu formula dalam jumlah besar saat bayi mengalami adiposity rebound pada usia 5-6 tahun dan peningkatan indeks massa tubuh dan persen lemak tubuh pada usia 7 tahun. ${ }^{6}$ Selain itu, konsumsi susu formula dalam jumlah besar saat bayi mungkin menyebabkan kecenderungan anak melanjutkan konsumsi susu hingga saat balita. Hasil penelitian ini menunjukkan bahwa $74.1 \%$ subjek pada kelompok kasus masih melanjutkan konsumsi susu hingga saat ini dibandingkan kelompok kontrol yang hanya $44.4 \%$ subjek. Apabila saat ini susu masih dikonsumsi dalam jumlah besar dan tidak disertai pengeluaran energi yang seimbang dengan asupan maka akan terjadi penumpukan energi yang akan mengakibatkan kegemukan pada balita. Pada penelitian ini, balita yang mengonsumsi susu formula dalam jumlah besar saat bayi juga cenderung memiliki asupan energi berlebih. Subjek pada kelompok kasus cenderung lebih banyak mengonsumsi jajanan cepat saji disamping asupan makanan utamanya, seperti mie instan, sosis goreng, dan roti bakar.

\section{KESIMPULAN}

Balita yang mengonsumsi susu formula $>100$ g/hari berisiko 7.0 kali lipat mengalami kegemukan.

\section{SARAN}

Ibu balita diberikan informasi mengenai pentingnya ASI eksklusif dan informasi kandungan nilai gizi dalam susu formula. Selain itu, ibu balita juga perlu diberi informasi mengenai dampak susu formula terhadap kegemukan balita. Penelitian akan lebih lengkap jika responden masih memiliki KMS anak yang digunakan setiap bulan penimbangan sehingga pemantauan berat badan setiap bulan akibat konsumsi susu formula dapat dipantau lebih tepat.

\section{UCAPAN TERIMAKASIH}

Puji dan syukur penulis panjatkan kehadirat Allah SWT atas segala rahmat dan karunia yang telah diberikan kepada penulis. Penulis mengucapkan terima kasih kepada ibu balita di Kelurahan Bangetayu Kulon dan Kelurahan Jangli yang bersedia menjadi responden. Penulis juga mengucapkan terima kasih kepada ibu Nurmasari Widyastuti S.Gz, M.Si. Med dan ibu Fillah Fithra Dienny, S.Gz, M.Si atas kritik dan sarannya untuk perbaikan karya tulis, kepada orangtua dan keluarga serta teman-teman atas dukungan dalam penelitian ini.

\section{DAFTAR PUSTAKA}

1. de Onis M, Blossner M, Borghi E. Global prevalence and trends of overweight and obesity among preschool children. The American journal of clinical nutrition. 2010;92(5):1257-64.DOI 10.3945/ajcn.2010.29786

2. Dinas Kesehatan Republik Indonesia. Riset Kesehatan Dasar. 2013.

3. Misra A, Shrivastava U. Obesity and dyslipidemia in South Asians. Nutrients. 2013;5(7):2708-33.DOI : 10.3390/nu5072708

4. Mayer-Davis EJ, et al. Breast-feeding and risk for childhood obesity: does maternal diabetes or obesity status matter? Diabetes care. 2006;29(10):22317.10.2337/dc06-0974

5. Kementrian Kesehatan Republik Indonesia. Situasi dan Analisis ASI Eksklusif. Pusat Data dan Informasi Kementrian Kesehatan Republik Indonesia. 2013

6. Gu“nther AL, Remer T, Kroke A, Buyken AE. Early protein intake and later obesity risk: which protein sources at which time points throughout infancy and childhood are important for body mass index and body fat percentage at7yof age?1-3. The American journal of clinical nutrition. 2007;86:1765-72. 
7. Baker JL, Michaelsen KF, Rasmussen KM, Sørensen TI. Maternal prepregnant body mass index, duration of breastfeeding, and timing of complementary food introduction are associated with infant weight gain. The American journal of clinical nutrition. 2004;80:1579 - 88.

8. Arnberg K, et al. Skim Milk, Whey, and Casein Increase Body Weight and Whey and Casein Increase the Plasma C-Peptide Concentration in Overweight Adolescents. Journal of Nutrition. 2012;142(12):2083-90.10.3945/jn.112.161208

9. Koletzko B, et al. Can infant feeding choices modulate later obesity risk? The American journal of clinical nutrition. 2009;89(5):1502S8S.10.3945/ajcn.2009.27113D

10. Hopkins D, Steer CD, Northstone K, Emmett PM. Effects on childhood body habitus of feeding large volumes of cow or formula milk compared with breastfeeding in the latter part of infancy. The American journal of clinical nutrition. 2015;102(5):1096-103.10.3945/ajcn.114.100529

11. Lestari P, Suyatno, Kartini A. Hubungan Praktik Pemberian Susu Formula Dengan Status Gizi Bayi Usia 0-6 Bulan Di Kecamatan Semarang Timur Kota Semarang. Jurnal Kesehatan Masyarakat (e-Journal). 2014;2(6).

12. Dahlan Sopiyudin. Besar Sampel dan Cara Pengambilan Sampel dalam Penelitian Kedokteran dan Kesehatan. Jakarta. EGC. 2009.

13. Zhang K, et al. Why Do Mothers of Young Infants Choose to Formula Feed in China? Perceptions of Mothers and Hospital Staff. Int. J. Environ. Res. Public Health 2015, 12, 4520-4532; doi:10.3390/ijerph120504520

14. Brown A, Raynor P, Lee M. Healthcare professionals' and mothers' perceptions of factors that influence decisions to breastfeed or formula feed infants: a comparative study. Wiley Online Library. 2011. doi 10.1111/j.1365-2648.2011.05647.x

15. Arora et al. Major Factors Influencing Breastfeeding Rates: Mother's Perception of Father's Attitude and Milk Supply. PEDIATRICS Vol. 106 No. 5 November 2000

16. Socha $\mathrm{P}$, et al. Milk protein intake, the metabolicendocrine response, and growth in infancy: data from a randomized clinical trial1-. The American journal of clinical nutrition. 2011;94(suppl):1776S84.10.3945/ajcn.110.000596.

17. Debra et al. The Effect of Breast-Feeding with and without Formula Use on the Risk of Obesity at 4 Years of Age. OBESITY RESEARCH Vol. 12 No. 9 September 2004.

18. Weber $\mathrm{M}$, et al. Lower protein content in infant formula reduces BMI and obesity risk at school age: follow-up of a randomized trial. The American journal of clinical nutrition. 2014.doi: 10.3945/ajcn.113.064071

19. Sulanto A. ASI sebagai faktor protektif obesitas pada anak. UGM, Yogyakarta, 2011.

20. Hester SN, Hustead DS, Mackey AD, Singhal A, Marriage BJ. Is the Macronutrient Intake of FormulaFed Infants Greater Than Breast-Fed Infants in Early
Infancy? Journal of Nutrition and Metabolism. 2012;12:13.http://dx.doi.org/10.1155/2012/891201

21. Ahmad QI, Ahmad CB, Ahmad SM. Childhood Obesity Indian Journal of Endocrinology and Metabolism. 2010;14(1):19-25

22. Arnberg K, et al. Skim Milk, Whey, and Casein Increase Body Weight and Whey and Casein Increase the Plasma C-Peptide Concentration in Overweight Adolescents. Journal of Nutrition. 2012;142(12):2083-90.10.3945/jn.112.161208

23. Koletzko B, et al. Can infant feeding choices modulate later obesity risk? The American journal of clinical nutrition. 2009;89(5):1502S8S.10.3945/ajen.2009.27113D

24. Sartika RAD. Faktor risiko obesitas pada anak 5-15 tahun di indonesia. Makara. 2011;15(1):37-43

25. Brown JE. Nutrition Throuh the Life Cycle. USA: Wadsworth; 2011. 